\title{
Clinical Outcome Study after External Approach Septoplasty
}

\author{
Do Yoon Jeong, Yoon Sik Park, and Ji Yun Choi \\ Department of Otorhinolaryngology-Head and Neck Surgery, College of Medicine, Chosun University, Gwangju, Korea
}

\author{
개방성 접근법에 의한 비중격 교정술의 임상 양상에 관한 연구 \\ 정도윤 · 박윤식 · 최지윤 \\ 조선대학교 의과대학 이비인후과학교실
}

Received June 23, 2020

Revised July 13,2020

Accepted July 28, 2020

Address for correspondence

Ji Yun Choi, MD, PhD

Department of Otorhinolaryngology-

Head and Neck Surgery,

College of Medicine,

Chosun University,

365 Pilmun-daero, Dong-gu,

Gwangju 61453, Korea

Tel $+82-62-220-3200$

Fax $+82-62-225-2702$

E-mail happyent@naver.com
Background and Objectives This study aims to investigate the indications of external approach septoplasty and improvement in subjective symptoms and objective parameters in patients who underwent external approach septoplasty to correct septal deviation with various types of deformities.

Subjects and Method Thirty-one patients who underwent external approach septoplasty from October 2014 to January 2019 were classified by direction, location, and degree of nasal septal deviation, septal shape and surgical techniques. Through acoustic rhinometry, the minimum cross-sectional area and nasal volume were measured before and after surgery. To evaluate the improvement in symptoms, the Nasal Obstruction Symptom Evaluation (NOSE) survey and nasal congestion visual analogue scale (VAS) were also measured.

Results We found significant correlations between: the direction and degree of nasal septal deviation; the location and degree of nasal septal deviation; septal shape and location of the nasal septal deviation; septal shape and surgical techniques; and the degree of nasal septal deviation and presence of spreader grafts. The NOSE scale following external approach septoplasty improved from $14.7 \pm 4.4$ to $3.1 \pm 3.2(p<0.001)$, while the VAS score improved from $7.2 \pm 2.3$ to $1.2 \pm 1.4(p<0.001)$. Also, acoustic rhinometry showed that the minimum cross-sectional area and nasal volume at the convex side of nasal cavity significantly increased after surgery. Conclusion The external approach septoplasty is a surgical technique that is effective not only in improving subjective symptoms, but also in improving objective parameters. External approach septoplasty could be used in case of caudal and/or dorsal nasal septal deviation.

Korean J Otorhinolaryngol-Head Neck Surg 2021;64(2):86-92

Key Words Nasal obstruction · Nasal septum · Rhinometry, acoustic $\cdot$ Rhinoplasty.

\section{서 론}

코막힘은 이비인후과 환자들이 호소하는 흔한 증상이며, 비중격 만곡은 코막힘의 가장 흔한 원인 중 하나이다. 비중격 교정술은 이비인후과 영역에서 흔하게 시행되는 기본적인 수

This is an Open Access article distributed under the terms of the Creative Commons Attribution Non-Commercial License (https://creativecommons.org/licenses/by-nc/4.0) which permits unrestricted non-commercial use, distribution, and reproduction in any medium, provided the original work is properly cited.
술로 비중격은 형태와 기형의 정도가 다양하며 비중격 만곡 을 교정하기 위한 수술 방법도 다양하다.1) 대다수의 비중격 교정술은 비강 내 접근법을 통해 시행된다. 하지만 심한 비중 격 만곡증이 있는 경우 비중격 변형을 교정하고 비첨부 지지 를 유지하기 위해서 비중격 연골부 및 골부로 완전한 접근이 필수적이다. ${ }^{2)}$ 개방성 접근법 비중격 교정술은 경비주 절개를 통해 비중격 전체 구조, 비첨, 키스톤 부위, 비밸브 부위를 노 출시켜 충분한 수술 시야를 제공하며, 연골 상부 비중격 만 
곡, 전단부 비중격 만곡, 키스톤 부위의 휘어짐, 비첨 변형, 짧 은 코 환자들이 적응증이 된다. ${ }^{3)}$

기존에 개방성 접근법 비중격 교정술의 기능적 개선 효과 를 알아보고자 하는 연구가 드물게 있었으나) 개방성 접근법 비중격 교정술의 유용성에 관해 국내에서 아직까지 보고된 바가 없다. 이에 본 연구에서는 다양한 형태의 변형을 보이는 비중격 만곡증의 교정을 위해 개방성 접근법 비중격 교정술 을 시행 받은 환자들을 후향적으로 분석하여 적용대상, 주관 적, 객관적 기능의 향상 및 유용성에 관해 알아보고자 하였다.

\section{대상 및 방법}

2014년 10월 2019년 1월까지 본원 이비인후과에서 단일 술자에게 개방성 접근법 비중격 교정술을 시행 받은 환자를 대상으로 임상 양상을 후향적으로 조사하였으며, 부비동 내 시경 검사, 음향 비강통기도 검사, 부비동 컴퓨터단층촬영, Nasal Obstruction Symptom Evaluation(NOSE) 설문지 ${ }^{5}$ 가 기록되어 있지 않거나 검사를 시행하지 않은 환자, 수술 전 증상 및 검사소견에서 알레르기 비염이 있는 환자는 본 연구 대상에서 제외하였다. 또한 부비동 내시경 수술, 비골 골절 정복술, 하비갑개 성형술 등 다른 수술을 같이 시행 받은 환 자들도 본 연구에서 제외하였다. 이 연구는 임상연구 심의위 원회의 승인(CHOSUN 2020-05-009-001)을 얻은 후 진행 되었다.

수술 전 비중격 만곡증의 방향, 위치, 만곡의 정도, 비중격 형태에 따라 분류를 시행하였다. 만곡증의 방향은 좌측 및 우측, 위치는 비중격 전단부 휘어짐, 비중격 상단부 휘어짐, 전단부와 상단부가 동시에 휘어짐으로 분류하였다. 만곡의 정도는 비중격 만곡이 비중격 측벽에 닿았을 때 심도, 측벽에 닿지는 않지만 수술이 필요할 정도로 심한 휘어짐을 중등도 로 분류하였다. 비중격 형태는 비중격의 모양에 따라 비중격 뒤틀림(septal tilt), 상·하방 C자 형태(superior-inferior Cshape), 전·후방 C자 형태(anterior-posterior C-shape), 상하방 S자 형태(superior-inferior S-shape), 전·후방 S자 형 태(anterior-posterior S-shape), 비중격극(septal spur)으로 구분하였다. ${ }^{6}$

음향 비강통기도 검사(acoustic rhinometer, ECCO vision 3.72, Hood Instruments, Pembroke, MA, USA)를 수술 전 및 수술 후 1 개월째 시행하였으며, 비강 입구에서부터 후방 $5.3 \mathrm{~cm}$ 까지 중 가장 작은 단면적 값을 측정한 최소 단면적 (minimal cross-sectional area)과 비공으로부터 후방 $5 \mathrm{~cm}$ 까지 측정한 비강 용적을 각각 좌 ·우측에서 비점막 수축제 사용 전·후로 측정하였다. 수술 후 환자의 주관적인 증상 개
선을 측정하기 위해 NOSE 설문지를 수술 전 및 수술 후 1 개 월째 시행하였으며, 코막힘 증상이 전혀 없는 경우를 0 점, 코 막힘 증상을 심하게 호소하는 경우를 10점으로 하는 visual analogue scale $(\mathrm{VAS})^{7)}$ 을 함께 측정하였다.

수술은 전신마취 하에 비중격, 비첨, 콧등(nasal bridge)에 국소마취를 시행한 후 11 번 메스를 이용하여 경비주 절개를 역 ‘V'자 형태로 넣고 15번 메스를 이용하여 비익연 절개와 연결하였다. 피부를 비익 연골 내측각과 외측각으로부터 박 리한 후 비익 연골, 비중격, 비골 노출을 위하여 상방으로 박 리를 시행하였다. 비중격 구조를 완전히 노출시킨 후 비중격 전방에서 시작하여 freer 거상기로 연골막을 거상하였다. 양 측 연골막을 충분히 거상하여 비중격 전체를 노출시킨 후 비 중격 연골을 사골 수직판 일부 및 서골(vomer)과 분리하였다. 비중격 만곡 부위를 절제한 후 채취된 연골은 이식을 위해 보 존하였다. 외비의 지지를 위해 비중격의 L 버팀목(L-strut)을 최소 1 1.5 cm 너비로 보존하였으며, 환자의 비중격 연골 전 단부 및 상단부의 만곡 교정을 위해 반회전문 술식(swing door technique), 버팀목 이식(batten graft), 비중격 미부 재 건술(caudal septal reconstruction), 비중격 체외교정술(extracorporeal septoplasty), 펼침 이식(spreader graft)을 시행 하였다. 비강 패킹은 수술 후 24시간 뒤에 제거하였다.

모든 자료는 SPSS ver.23.0(IBM Corp., Armonk, NY, $\mathrm{USA}$ )으로 분석하였다. 비중격 만곡증의 방향, 위치, 만곡의 정도, 비중격 형태, 수술 방법, 펼침 이식 여부 간의 관련성 확인을 위해 Cramer's V test, 수술 전 및 수술 후 1개월째 시 행한 NOSE 점수, 코막힘 VAS 점수, 비중격 만곡증의 볼록 면에서 비점막 수축제 사용 전·후로 측정한 최소 단면적과 비강 용적의 수술 전·후 변화를 알아보기 위해 paired t-test, 비중격 만곡의 정도, 만곡증의 위치, 비중격 형태에 따른 NOSE 점수, 코막힘 VAS 점수, 최소 단면적과 비강 용적의 수술 전 및 수술 후 변화를 확인하기 위해 사후검정으로 Wilcoxon signed rank test를 이용하여 유의성을 검증하였고, $p$ 값이 0.05 미만일 때 통계적 유의성이 있다고 판단하였다.

\section{결 과}

총 31 명의 환자가 본 연구에 포함되었고, 남자가 29명, 여자

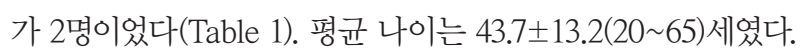
수술 전 비중격 만곡은 우측으로 16 명, 좌측으로 15 명으로 좌·우측의 차이는 거의 없었으며, 비중격 만곡증의 위치는 비중격 전단부의 휘어짐이 17 명, 비중격 상단부의 휘어짐이 1 명, 전단부와 상단부가 동시에 휘어짐이 13 명 관찰되었다. 비중격 만곡의 정도는 중증도가 11 명, 심도가 20 명이었다. 
Guyuron 분류 ${ }^{6}$ 에 따른 비중격 형태는 I(뒤틀림), II(상·하방 $\mathrm{C}$ 자 형태)가 각각 11 명으로 가장 많았고, $\mathrm{III}($ 전· 후방 C자 형 태)가 1명, IV(상·하방 S자 형태)가 7명, V(전·후방 S자 형태) 가 1명이었다. 비중격 만곡증 수술을 위해 사용된 주된 방법 은 반회전문 술식이 12 명, 버팀목 이식이 12 명, 비중격 미부 재건술이 6 명, 비중격 체외교정술이 1명이었다. 펼침 이식을 사용한 환자는 10 명이었으며, 재수술인 환자는 5 명이었다.

Table 1. Demography of patients $(n=31)$

\begin{tabular}{|c|c|}
\hline Variables & Number or mean $\pm S D$ \\
\hline Age, yr & $43.7 \pm 13.2$ \\
\hline Gender, M:F & $29: 2$ \\
\hline \multicolumn{2}{|l|}{ Direction of septal deviation (\%) } \\
\hline Right & $16(51.6)$ \\
\hline Left & $15(48.4)$ \\
\hline \multicolumn{2}{|l|}{ Location of septal deviation (\%) } \\
\hline Caudal & $17(54.8)$ \\
\hline Dorsal & $1(3.2)$ \\
\hline Caudal \& dorsal & $13(41.9)$ \\
\hline \multicolumn{2}{|l|}{ Degree of septal deviation (\%) } \\
\hline Moderate & $11(35.5)$ \\
\hline Severe & $20(64.5)$ \\
\hline \multicolumn{2}{|l|}{ Septal shape (\%) } \\
\hline Septal tilt & $11(35.5)$ \\
\hline Superior-inferior C-shape & $11(35.5)$ \\
\hline Anterior-posterior C-shape & $1(3.2)$ \\
\hline Superior-inferior S-shape & $7(22.6)$ \\
\hline Anterior-posterior S-shape & $1(3.2)$ \\
\hline \multicolumn{2}{|l|}{ Surgical techniques (\%) } \\
\hline Swing door technique & $12(38.7)$ \\
\hline Batten graft & $12(38.7)$ \\
\hline Caudal septal reconstruction & $6(19.4)$ \\
\hline Extracoporeal septoplasty & $1(3.2)$ \\
\hline Presence of spreader graft (\%) & $10(32.3)$ \\
\hline Presence of revision operation (\%) & $5(16.1)$ \\
\hline Complication (\%) & $0(0)$ \\
\hline
\end{tabular}

SD: standard deviation, $\mathrm{M}$ : male, F: female
비중격 만곡증의 방향과 정도(Cramer's V=0.361, $p=0.044$ ), 비중격 만곡증의 위치와 정도(Cramer's $\mathrm{V}=0.538, p=0.011$, 비중격 형태와 비중격 만곡증 위치(Cramer's V=0.779, $p<$ 0.001), 비중격 만곡증의 정도와 펼침 이식 여부(Cramer's V= $0.368, p=0.041)$ 간에는 통계적으로 유의한 상관관계가 관찰 되었다. 비중격 형태와 사용된 수술방법 간에도 통계적으로 유의한 상관관계가 관찰되었다(Cramer's $\mathrm{V}=0.864, p<0.001$ ) (Table 2).

수술 전 평균 $\mathrm{NOSE}$ 점수는 $14.7 \pm 4$.4점이었고, 수술 후 $3.1 \pm 3.2$ 점으로 통계적으로 유의하게 감소되었다 $(p<0.001)$. 수술 전 평균 코막힘 VAS 점수는 7.2 \pm 2.3 점, 수술 후 $1.2 \pm$ 1.4 점으로 통계적으로 유의하게 감소되었다 $(p<0.001)$ (Fig. 1).

비중격 만곡증의 볼록면에서 측정한 음향 비강통기도 검사 결과는 비점막 수축제 사용 전 최소 단면적은 수술 전 0.35 $\pm 0.15 \mathrm{~cm}^{2}$, 수술 후 $0.47 \pm 0.10 \mathrm{~cm}^{2}$ 였고, 비점막 수축제 사용 후 최소 단면적은 수술 전 $0.40 \pm 0.14 \mathrm{~cm}^{2}$, 수술 후 $0.47 \pm 0.09$ $\mathrm{cm}^{2}$ 로 수술 후 볼록면 최소 단면적이 통계적으로 유의하게 증가하였다 $(p<0.001, p=0.013)$. 비점막 수축제 사용 전 볼록 면 비강 용적은 수술 전 $4.99 \pm 2.87 \mathrm{~cm}^{3}$, 수술 후 $7.10 \pm 2.07$ $\mathrm{cm}^{3}$ 였고, 비점막 수축제 사용 후 볼록면 비강 용적은 수술 전 $5.34 \pm 2.44 \mathrm{~cm}^{3}$, 수술 후 $7.85 \pm 2.26 \mathrm{~cm}^{3}$ 로 비점막 수축제 사용 여부와 관계없이 수술 후 볼록면 비강 용적이 통계적으 로 유의하게 증가하였다 $(p<0.001, p<0.001)$ (Fig. 2).

중등도의 비중격 만곡이 있는 환자에서 NOSE 점수 및 코 막힘 VAS 점수는 수술 이후 통계적으로 유의하게 감소되었 으나 음향 비강통기도 검사에서는 비점막 수축제 사용 여부 와 관계없이 통계적으로 유의하지 않았다. 심도의 비중격 만 곡 정도 환자에서는 NOSE 점수, 코막힘 VAS 점수는 개방성 접근법 비중격 교정술 이후 통계적으로 유의하게 감소되었으 며, 음향 비강통기도 검사에서는 비점막 수축제 사용 여부와 관계없이 비강 용적만 수술 이후 통계적으로 유의하게 증가 하였다(Table 3).

Table 2. Cross tabulation between septal shape and surgical techniques

\begin{tabular}{lcccc}
\hline & \multicolumn{2}{c}{ Surgical techniques } \\
\cline { 2 - 4 } & $\begin{array}{c}\text { Swing door } \\
\text { technique }\end{array}$ & Batten graft & $\begin{array}{c}\text { Caudal septal } \\
\text { reconstruction }\end{array}$ & $\begin{array}{c}\text { Extracoporeal } \\
\text { septoplasty }\end{array}$ \\
\hline $\begin{array}{l}\text { Septal shape } \\
\text { Septal tilt }\end{array}$ & 9 & 2 & 0 & 0 \\
Superior-inferior C-shape & 2 & 9 & 0 & 0 \\
Anterior-posterior C-shape & 1 & 0 & 0 & 0 \\
Superior-inferior S-shape & 0 & 1 & 6 & 0 \\
Anterior-posterior S-shape & 0 & 0 & 0 & 1 \\
Septal shape $\times$ surgical techniques & & & & $<0.001^{\dagger}$ \\
\hline * correlation analysis by Cramer's V, tstatistically significant
\end{tabular}




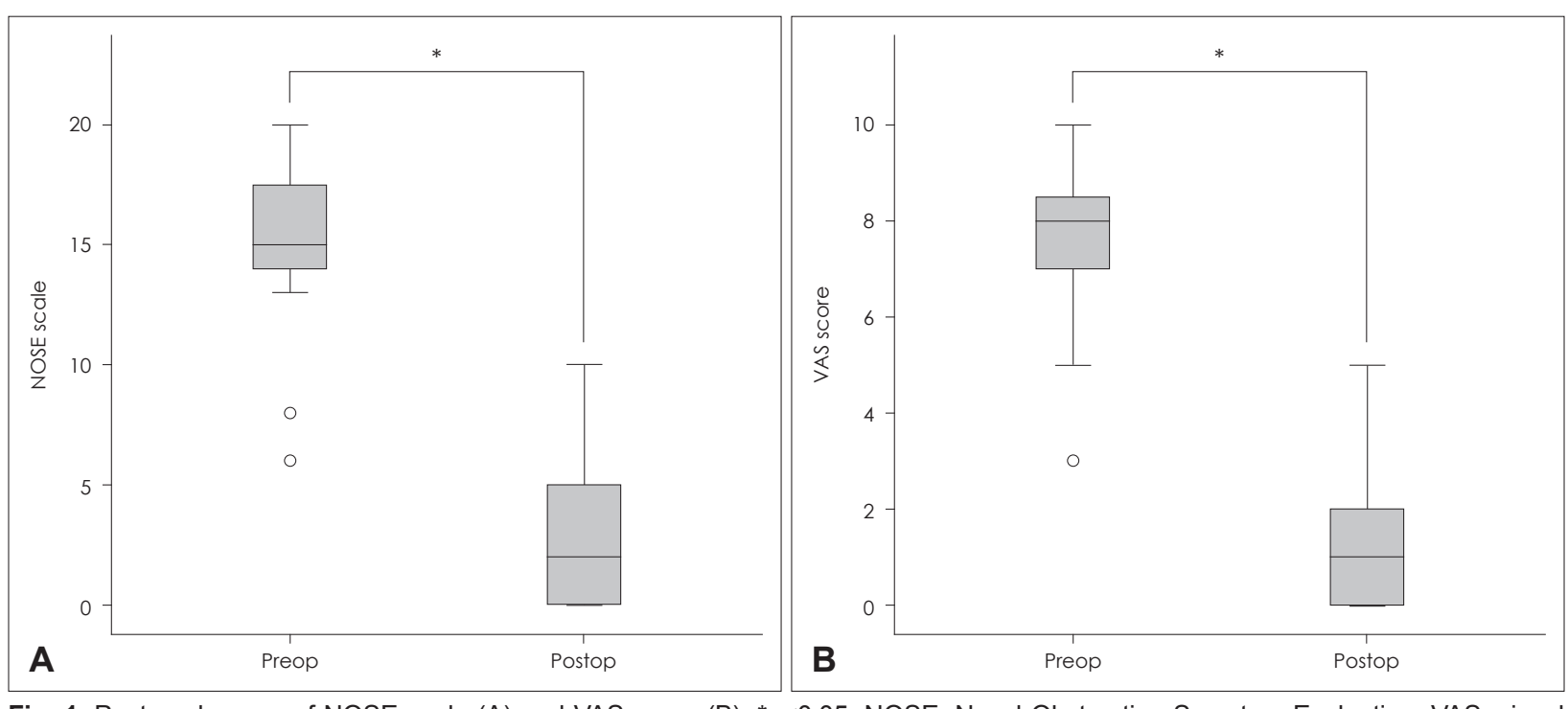

Fig. 1. Postop changes of NOSE scale (A) and VAS score (B). ${ }^{*} p<0.05$. NOSE: Nasal Obstruction Symptom Evaluation, VAS: visual analogue scale, preop: preoperative, postop: postoperative.
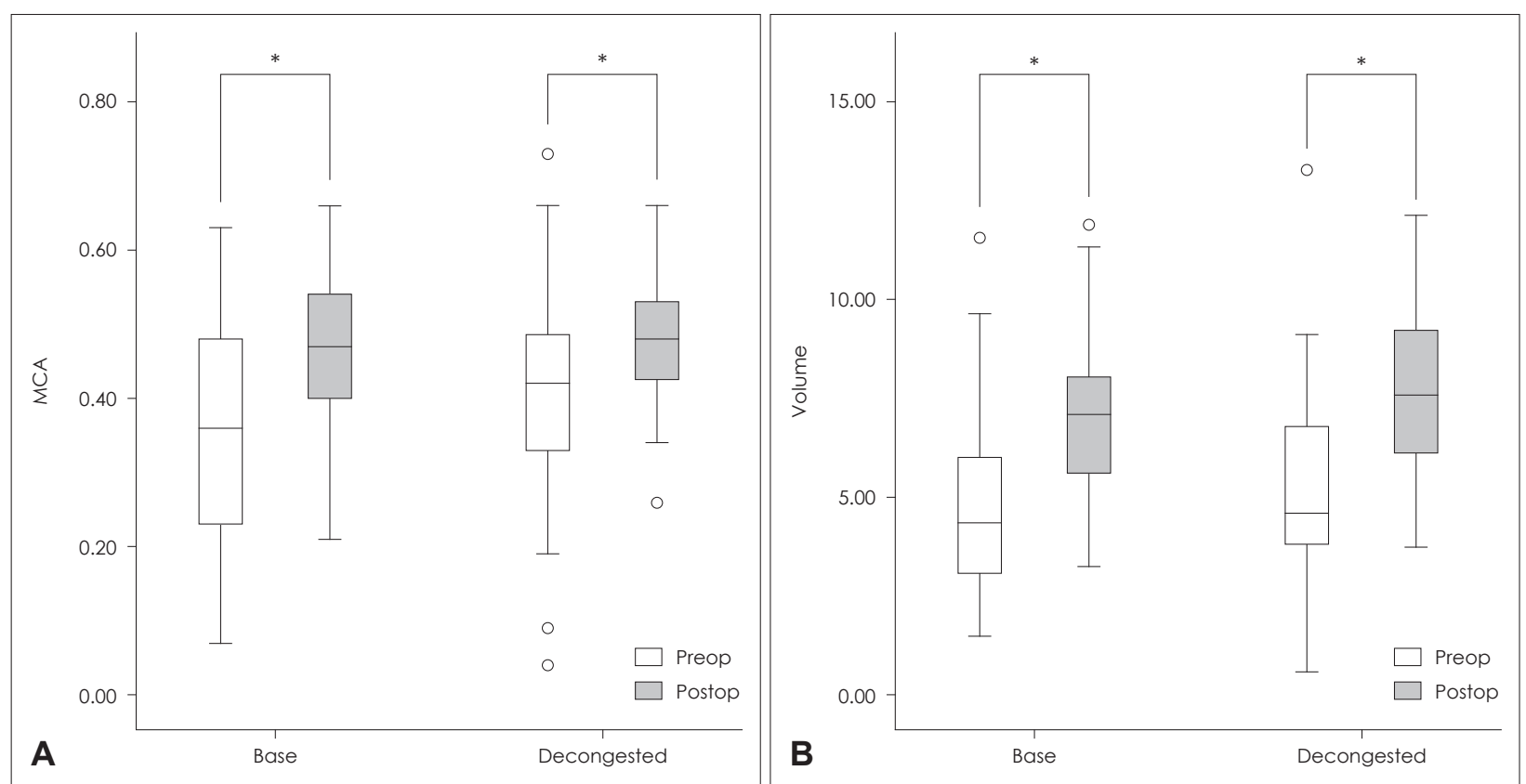

Fig. 2. Postop changes of MCA (A) and nasal volume (B) by acoustic rhinometry on convex side of nasal cavity. ${ }^{*} p<0.05$. MCA: minimal cross-sectional area, preop: preoperative, postop: postoperative.

비중격 전단부가 휘어진 경우는 NOSE 점수, 코막힘 $\mathrm{VAS}$ 점수가 수술 후 통계적으로 유의하게 감소하였으며, 음향 비 강통기도 검사에서는 비점막 수축제 사용 전 비강 용적이 수 술 후 통계적으로 유의하게 증가하였다. 비중격 전단부와 상 단부가 동시에 휘어진 경우는 NOSE 점수 및 코막힘 VAS 점 수가 수술 후 통계적으로 유의하게 감소하였으며, 음향 비강 통기도 검사에서는 비점막 수축제 사용 후 비강 용적이 수술 후 통계적으로 유의하게 증가하였다. 비중격 상단부가 휘어진 경우는 본 연구에서 1 명의 환자로 통계 분석 시 제외하였다
(Table 4).

Guyuron 분류)에서 I은 수술 후 NOSE 점수, 코막힘 VAS 점수가 통계적으로 유의하게 감소하였으며, 음향 비강통기도 검사에서는 비점막 수축제 사용 전 비강 용적만 통계적으로 유의하게 증가하였고, II, IV는 NOSE 점수 및 코막힘 VAS 점수만 수술 후 통계적으로 유의하게 감소하였다. III, V는 본 연구에서 각각 1 명의 환자로 통계 분석 시 제외하였다(Table 5). 모든 환자에서 추적관찰 기간 동안 구조적 합병증, 감 염, 혈종, 비중격 천공, 유착 등의 합병증은 나타나지 않았다. 
Table 3. Comparison of the values obtained from preop and postop NOSE scale, VAS score, acoustic rhinometry results according to the degree of septal deviation

\begin{tabular}{|c|c|c|c|c|}
\hline & \multicolumn{4}{|c|}{ Degree of septal deviation } \\
\hline & \multicolumn{2}{|c|}{ Moderate } & \multicolumn{2}{|c|}{ Severe } \\
\hline & Z-value & $p$-value* & Z-value & p-value* \\
\hline NOSE scale & $-2.95 \S$ & $0.003^{\dagger}$ & $-3.83^{\ddagger}$ & $<0.001^{\dagger}$ \\
\hline VAS & $-2.97 \S$ & $0.003^{\dagger}$ & $-3.84^{\ddagger}$ & $<0.001^{\dagger}$ \\
\hline MCA preop/postop, baseline & $-0.22 \S$ & 0.824 & $-1.76 \S$ & 0.079 \\
\hline MCA preop/postop, decongested & $-0.22 \S$ & 0.824 & $-0.38 \S$ & 0.702 \\
\hline Volume preop/postop, baseline & $-1.16 \S$ & 0.248 & $-2.28 \S$ & $0.023^{\dagger}$ \\
\hline Volume preop/postop, decongested & $-1.07 \S$ & 0.286 & $-2.73 \S$ & $0.006^{\dagger}$ \\
\hline
\end{tabular}

*Wilcoxon signed rank test, tstatistically significant, fbased on positive ranks, sbased on negative ranks. NOSE: Nasal Obstruction Symptom Evaluation, VAS: visual analogue scale, MCA: minimal cross-sectional area, preop: preoperative, postop: postoperative

Table 4. Comparison of the values obtained from preop and postop NOSE scale, VAS score, acoustic rhinometry results according to the location of septal deviation

\begin{tabular}{|c|c|c|c|c|}
\hline & \multicolumn{4}{|c|}{ Location of septal deviation } \\
\hline & \multicolumn{2}{|c|}{ Caudal } & \multicolumn{2}{|c|}{ Caudal \& dorsal } \\
\hline & Z-value & p-value* & Z-value & p-value* \\
\hline NOSE scale & $-3.63^{\ddagger}$ & $<0.001^{\dagger}$ & $-3.07 \ddagger$ & $0.002^{\dagger}$ \\
\hline VAS & $-3.64^{\ddagger}$ & $<0.001^{\dagger}$ & $-3.07^{\ddagger}$ & $0.002^{\dagger}$ \\
\hline MCA preop/postop, baseline & $-1.30 \$$ & 0.193 & $-1.15^{\S}$ & 0.249 \\
\hline MCA preop/postop, decongested & $-0.60 \$$ & 0.552 & $-0.45 \S$ & 0.650 \\
\hline Volume preop/postop, baseline & $-1.97 \S$ & $0.049+$ & $-1.50 \S$ & 0.133 \\
\hline Volume preop/postop, decongested & $-1.68 \S$ & 0.093 & $-2.76 \S$ & $0.006^{\dagger}$ \\
\hline
\end{tabular}

*Wilcoxon signed rank test, tstatistically significant, fbased on positive ranks, sbased on negative ranks. NOSE: Nasal Obstruction Symptom Evaluation, VAS: visual analogue scale, MCA: minimal cross-sectional area, preop: preoperative, postop: postoperative

Table 5. Comparison of the values obtained from preop and postop NOSE scale, VAS score, acoustic rhinometry results according to septal shape

\begin{tabular}{|c|c|c|c|c|c|c|}
\hline & \multicolumn{6}{|c|}{ Septal shape } \\
\hline & \multicolumn{2}{|c|}{ Septal tilt } & \multicolumn{2}{|c|}{ Superior-inferior C-shape } & \multicolumn{2}{|c|}{ Superior-inferior S-shape } \\
\hline & Z-value & $p$-value* & Z-value & p-value* & Z-value & $p$-value* \\
\hline NOSE scale & $-2.94^{\ddagger}$ & $0.003^{+}$ & $-2.81^{\ddagger}$ & $0.005^{\dagger}$ & $-2.38^{\ddagger}$ & $0.018^{+}$ \\
\hline VAS & $-2.94^{\ddagger}$ & $0.003^{\dagger}$ & $-2.84^{\ddagger}$ & $0.004^{\dagger}$ & $-2.39 \ddagger$ & $0.017^{\dagger}$ \\
\hline MCA preop/postop, baseline & $-0.98 \S$ & 0.328 & $-1.07 \S$ & 0.286 & $-0.85 \S$ & 0.398 \\
\hline MCA preop/postop, decongested & $-0.26 \neq$ & 0.799 & $-0.53 \S$ & 0.594 & $-0.68 \S$ & 0.499 \\
\hline Volume preop/postop, baseline & $-2.22 \S$ & $0.026^{\dagger}$ & $-0.36 \S$ & 0.722 & $-1.52 \S$ & 0.128 \\
\hline Volume preop/postop, decongested & $-1.96 \S$ & 0.050 & $-1.42 \S$ & 0.155 & $-1.36 \$$ & 0.176 \\
\hline
\end{tabular}

*Wilcoxon signed rank test, tstatistically significant, fbased on positive ranks, sbased on negative ranks. NOSE: Nasal Obstruction Symptom Evaluation, VAS: visual analogue scale, MCA: minimal cross-sectional area, preop: preoperative, postop: postoperative

\section{고 찰}

비중격 만곡증이 확인된 경우 어떠한 수술적 접근 방식이 효과적인지에 대한 정보를 제공하는 연구는 드물다. Guyuron 등으는 비중격 만곡을 분류하는 시도를 하였으며, 전단 부 비중격 만곡의 경우 편측 또는 양측의 펼침 이식과 개방성 접근법을 통해 성공적인 결과를 얻을 수 있음을 보고하였고, Chaaban 등은 개방성 접근법 비중격 교정술의 적응증이 되는 환자를 제시하였다. 개방성 접근법 비중격 교정술의 대
상은 전단부 및/또는 상단부 비중격 만곡증과 코의 기능상의 문제가 있으면서 비첨 변형이 있는 경우 기본적인 접근 방식 으로 여겨진다. 본 연구에서는 비중격 만곡이 전단부 휘어짐 및 전단부와 상단부가 동시에 휘어진 경우, 그리고 중증도 이 상의 만곡을 가지고 있는 환자에서 개방성 접근법 비중격 교 정술을 시행하였다.

비중격 전단부 변형이 존재하는 경우 Metzenbaum은 반 회전문 술식의 유용성을 보고하였으며, $\mathrm{Choi}^{9}$ 는 비중격 뒤 틀림이나 상·하방 C자 형태로 휘어져 있는 경우 반회전문 술 
식이 효과적인 방법으로 제시하였다. Wee 등미은 버팀목 이 식이 중증도 및 심도의 비중격 만곡증이 있는 경우 코막힘 증상 개선, 볼록면에서 최소 단면적과 비강 용적이 증가됨을 보고하였으며, Chung 등 ${ }^{11)}$ 의 연구에서는 비중격 전단부 만곡 증에서 골부목 이식이 효과적이었다. 비중격 미부 재건술은 비중격 전단부의 심한 만곡으로 비밸브 협착이 있는 경우 효 과적인 술식이며, ${ }^{12)}$ 비중격 체외교정술은 외상, 이전 수술 또 는 선천 기형과 같이 비중격 변형이 매우 심한 경우 적응증이 되는 술식이다. ${ }^{13)}$ 본 연구에서 비중격 형태와 수술 방법, 비중 격 만곡증의 정도와 펼침 이식 여부 간에 통계적으로 유의한 상관관계가 있었으며, 비중격 뒤틀림과 전·후방 C자 형태는 반회전문 술식, 상-하방 $\mathrm{C}$ 자 형태는 버팀목 이식, 상-하방 $\mathrm{S}$ 자 형태는 비중격 미부 재건술, 전·후방 $\mathrm{S}$ 자 형태는 비중격 체외교정술, 심도의 비중격 만곡증에서 펼침 이식이 효과적 이었다.

코의 전단부는 가장 좁은 부위인 비밸브를 포함하고 있다. 내비 밸브는 비중격과 비익 연골의 사이의 구조로 흡기류의 일차적 결정 부위이며, 비강의 최소 단면적에 상응한다. 전단 부 비중격 만곡증이나 상단부 비중격 만곡증에 의한 내비 밸 브의 협착은 비강 내 기류의 높은 저항을 일으킨다. 개방성 접근법 비중격 교정술은 비밸브 중 특히 내비 밸브 부위를 직접적으로 노출시키고 비중격 만곡과 편향을 수술적으로 교정할 수 있게 해준다. 내비 밸브와 함께 상단부 비중격을 교정하는 것이 비강 내 기류를 저명하게 개선시켜준다.2)

코막힘 증상은 평가하기 어려운 증상 중 하나로 다양한 생 리학적 그리고 심리학적인 인자로부터 영향을 받는다. 비개방 성 비중격 교정술의 결과에 대해 많은 연구들이 높은 환자의 만족도를 보고하고 있다. ${ }^{14,15)}$ Kahveci 등 ${ }^{16)}$ 은 NOSE 점수가 코막힘 증상을 평가하는 데 사용될 수 있으며, 비개방성 비 중격 교정술 이후 $\mathrm{NOSE}$ 점수 및 코막힘 $\mathrm{VAS}$ 점수가 호전 되었으며, NOSE 점수의 개선이 코막힘 VAS 점수와도 연관 되며 비중격 교정술의 결과를 평가하는 데 매우 효과적인 도 구임을 보고하였다.

$\mathrm{Han}$ 등 $^{17)}$ 은 비개방성 비중격 교정술 이후 음향 비강통기도 검사상 오목면 및 볼록면의 최소 단면적 및 비강 용적 증가를 보고하였다. 본 연구에서는 개방성 접근법 비중격 교정술 시 행 후 NOSE 점수 및 코막힘 $\mathrm{VAS}$ 점수는 비중격 만곡증의 방향, 위치, 정도, 비중격 형태에 관계없이 모두 호전되었고, 객관적인 검사인 음향 비강통기도 검사에서도 볼록면의 최소 단면적과 비강 용적이 증가하는 소견이 관찰되었으며 비개방 성 비중격 교정술을 시행한 기존 연구 결과와 비슷한 결과가 도출되었다.

본 연구는 선택된 연구집단이 크지 않아 전체 환자를 대상
으로 한 음향 비강통기도 검사에서는 수술 전·후로 최소 단 면적과 비강 용적이 통계적으로 유의하게 증가된 결과를 보 였으나 소집단으로 나뉘어 분석한 결과는 음향 비강통기도 검사상 통계적으로 유의하지 않은 결과가 많았으며, 이는 소 집단의 연구 대상 수가 작아 도출된 것으로 사료된다. 추후 연구에서는 많은 연구 대상 설정과 전향적 연구가 필요할 것 을 생각된다.

\section{Acknowledgments}

None.

\section{Author Contribution}

Conceptualization: Ji Yun Choi. Data curation: all authors. Formal analysis: Do Yoon Jeong, Yoon Sik Park. Funding acquisition: Ji Yun Choi. Investigation: all authors. Methodology: all authors. Project administration: Ji Yun Choi. Supervision: Ji Yun Choi. Validation: Ji Yun Choi. Visualization: all authors. Writing-original draft: all authors. Writing — review \& editing: all authors.

\section{ORCID}

Ji Yun Choi

https://orcid.org/0000-0002-6097-3141

\section{REFERENCES}

1) Tompos T, Garai T, Zemplén B, Gerlinger I. Sensation of nasal patency compared to rhinomanometric results after septoplasty. Eur Arch Otorhinolaryngol 2010;267(12):1887-91.

2) Gupta A, Brooks D, Stager S, Lindsey WH. Surgical access to the internal nasal valve. Arch Facial Plast Surg 2003;5(2):155-8.

3) Chaaban M, Shah AR. Open septoplasty: Indications and treatment. Otolaryngol Clin North Am 2009;42(3):513-9.

4) Phillips PS, Stow N, Timperley DG, Sacks R, Srubiski A, Harvey RJ, et al. Functional and cosmetic outcomes of external approach septoplasty. Am J Rhinol Allergy 2011;25(5):351-7.

5) Stewart MG, Witsell DL, Smith TL, Weaver EM, Yueh B, Hannley MT. Development and validation of the Nasal Obstruction Symptom Evaluation (NOSE) scale. Otolaryngol Head Neck Surg 2004;130(2): 157-63.

6) Guyuron B, Uzzo CD, Scull H. A practical classification of septonasal deviation and an effective guide to septal surgery. Plast Reconstr Surg 1999;104(7):2202-9; discussion 2210-2.

7) Kim YI, Lee WS, Park HN, Chae WS, Jin HC, Lee JS, et al. Analysis of methods for pain measurement used in Journal of the Korean Pain Society. Korean J Pain 2003;16(1):33-6.

8) Metzenbaum M. Replacement of the lower end of the dislocated septal cartilage versus submucous resection of the dislocated end of the septal cartilage. Arch Otolaryngol 1929;9(3):282-96.

9) Choi JY. Revision and reconstructive septoplasty. Korean J Otorhinolaryngol-Head Neck Surg 2016;59(8):571-7.

10) Wee JH, Lee JE, Cho SW, Jin HR. Septal batten graft to correct cartilaginous deformities in endonasal septoplasty. Arch Otolaryngol Head Neck Surg 2012;138(5):457-61.

11) Chung YS, Seol JH, Choi JM, Shin DH, Kim YW, Cho JH, et al. How to resolve the caudal septal deviation? Clinical outcomes after septoplasty with bony batten grafting. Laryngoscope 2014;124(8): 1771-6.

12) Surowitz J, Lee MK, Most SP. Anterior septal reconstruction for treatment of severe caudal septal deviation: Clinical severity and outcomes. Otolaryngol Head Neck Surg 2015;153(1):27-33.

13) Gubisch W. Twenty-five years experience with extracorporeal 
septoplasty. Facial Plast Surg 2006;22(4):230-9.

14) Konstantinidis I, Triaridis S, Triaridis A, Karagiannidis K, Kontzoglou G. Long term results following nasal septal surgery. Focus on patients' satisfaction. Auris Nasus Larynx 2005;32(4):369-74.

15) Pirilä T, Tikanto J. Unilateral and bilateral effects of nasal septum surgery demonstrated with acoustic rhinometry, rhinomanometry, and subjective assessment. Am J Rhinol 2001;15(2):127-33.
16) Kahveci OK, Miman MC, Yucel A, Yucedag F, Okur E, Altuntas A. The efficiency of Nose Obstruction Symptom Evaluation (NOSE) scale on patients with nasal septal deviation. Auris Nasus Larynx 2012;39(3):275-9.

17) Han SJ, Oh H, Park YK, Min SG, Shin JH, Lee WW, et al. Should the high septal deviation be corrected to improve nasal obstruction during septal surgery? J Rhinol 2016;23(2):85-90. 